\title{
Morphogenesis of age groups of Marandu palisade grass tillers deferred and fertilised with nitrogen
}

\section{Morfogênese de faixas etárias de perfilhos do capim-marandu diferido e adubado com nitrogênio}

\author{
Lucas Coelho Alves ${ }^{1}$; Manoel Eduardo Rozalino Santos ${ }^{2 *}$; Lilian Elgalise Techio \\ Pereira $^{3}$; Angélica Nunes de Carvalho ${ }^{4}$; Gabriel de Oliveira Rocha ${ }^{4}$; \\ Bruno Humberto Rezende Carvalho ${ }^{4}$; Kathleen Alves Vasconcelos; \\ Amanda Bortoleto Ávila ${ }^{1}$
}

\begin{abstract}
Nitrogen fertilisation allows to modulate the growth of forage canopy during the deferment period. We evaluated the morphogenic characteristics, during the initial and final phases of the deferment period, of young, mature and old tillers of Brachiaria brizantha cv. Marandu. fertilised with low and high doses of nitrogen $(\mathrm{N})$. The design was completely randomised, in a subdivided plot scheme, with four replications. Leaf appearance rate (LAR) and leaf elongation rate (LER) were higher in young tillers than in old ones. At the beginning of the deferment period, the canopy under high $\mathrm{N}$ doses had higher LAR and LER values. At the end of the deferment period, we observed no difference between the doses of $\mathrm{N}$ for LAR. The stem elongation rate was higher at the beginning than at the end of the deferment period, while the leaf senescence rate (LSR) was higher at higher $\mathrm{N}$ doses when compared to lower doses. The highest LSR values and leaf lifespan were observed at the end of the deferment period. The greatest number of young tillers occurred at the beginning of the deferment period and with the highest $\mathrm{N}$ dose. In this sense, higher $\mathrm{N}$ doses, applied during the active growth period and before the deferment period, favour he maintenance of a larger number of young tillers, which have a greater growth potential. Key words: Brachiaria brizantha. Deferment. Leaf growth. Senescence. Stem elongation.
\end{abstract}

\section{Resumo}

A adubação nitrogenada permite modular o crescimento do dossel forrageiro durante o período de diferimento. Objetivou-se avaliar, durante as fases inicial e final do período de diferimento, as características morfogênicas de perfilhos jovens, maduros e velhos da Brachiaria brizantha cv. Marandu

\footnotetext{
${ }^{1}$ Zootecnistas, Universidade Federal de Uberlândia, UFU, Faculdade de Medicina Veterinária, Uberlândia, MG, Brasil. E-mail: lucascoelho zootecnia@hotmail.com; amanda bortoleto@yahoo.com

2 Prof. Dr., UFU, Faculdade de Medicina Veterinária, Programa de Pós-Graduação em Ciências Veterinárias, Uberlândia, MG, Brasil. E-mail: manoel.rozalino@ufu.br

3 Prof ${ }^{a}$ Dra $^{\text {a }}$ Universidade de São Paulo, USP, Faculdade de Zootecnia e Engenharia de Alimentos, Departamento de Zootecnia, Programa de Pós-Graduação em Zootecnia, Pirassununga, SP, Brasil. E-mail: 1techio@usp.br

4 Zootecnistas, Discentes, Curso de Doutorado do Programa de Pós-Graduação em Ciências Veterinárias, Universidade Federal de Uberlândia, Uberlândia, MG, Brasil. E-mail: angelicanunescoro@hotmail.com; gabriel.o.rocha@hotmail.com.br; brunohrc16@ hotmail.com

5 Zootecnista, Discente, Curso de Mestrado do Programa de Pós-Graduação em Ciências Veterinárias, UFU, Uberlândia, MG, Brasil. E-mail: kath.alves31@hotmail.com

Author for correspondence
} 
adubada com doses baixa e alta de nitrogênio $(\mathrm{N})$. O delineamento foi inteiramente casualizado, em esquema de parcela subsubdivida, com quatro repetições. As taxas de aparecimento (TApF) e de alongamento foliar (TAlF) foram maiores em perfilhos jovens do que nos velhos. No início do diferimento o dossel sob alta dose de $\mathrm{N}$ teve maiores TApF e TAlF. No fim do diferimento não houve diferença entre as doses de $\mathrm{N}$ para TAlF. A taxa de alongamento de colmo foi superior no início do que no fim do diferimento. A taxa de senescência foliar (TSeF) foi maior com a alta dose de N, quando comparado à baixa dose. As maiores TSeF e duração de vida da folha ocorreram no fim, em comparação ao início do diferimento. O maior número de perfilhos jovens ocorreu no início do diferimento e com a maior dose de N. A maior dose N, parcelada durante o período de crescimento ativo da planta, antes do diferimento, favorece a manutenção de maior número de perfilho jovem, o qual tem maior potencial de crescimento.

Palavras-chave: Alongamento de colmo. Brachiaria brizantha. Crescimento foliar. Diferimento. Perfilhamento. Senescência.

\section{Introduction}

Pasture deferment aims to ensure feed supply to animals kept on pastures during periods of low forage growth (SANTOS et al., 2009). Failure to adopt adequate management strategies, combined with a lack of knowledge about the ability to adjust morphological characteristics and potential changes in the plant population over the deferral period, led to the consensus that deferred pastures are characterised by excess dead material as well as high low nutritional values (SILVA et al., 2016). In this context, it is worth mentioning that because of the climatic conditions in winter, even when well-managed, deferred pastures have a structure and nutritional value more unfavourable for animal performance when compared to non-deferred pasture used during spring and summer.

However, recent studies on tropical forage grasses, aimed at understanding the adaptive mechanisms of plants used for forage production, have emphasised the importance of adopting management strategies as a way to modulate the growth of deferred pastures (SOUSA et al., 2013; TEIXEIRA et al., 2014). Thus, by identifying the most suitable time of starting the deferment period in a particular region, the variations in deferment period (SANTOS et al., 2009), the control of pasture height at the beginning of the deferment period (SOUSA et al., 2013) and the nitrogen fertilisation strategy (TEIXEIRA et al., 2014) can be used to define the amount of forage produced as well as the structure and nutritive value of the deferred pasture.

Strategic nitrogen fertilisation has a substantial effect on the growth characteristics of deferred pastures, allowing a reduction in the duration of the deferment period without reducing or even increasing forage production during this time frame (SOUSA et al., 2012). According to Caminha et al. (2010), nitrogen fertilisation increases the renewal of tillers via increasing appearance and mortality rates and alters the age profile of the population. An increase in the percentage of tillers up to an age of 2 months (classified as young) in spring and summer, with increasing nitrogen doses, has been recorded by Paiva et al. (2011) in Marandu grass pastures (Brachiaria brizantha syn., Urochloa brizantha Stapf, cv. Marandu) kept at $30 \mathrm{~cm}$ under continuous stocking. The tillers of this age group were also more responsive to nitrogen fertilisation. In addition, young tillers showed higher rates of appearance and leaf elongation (BARBOSA et al., 2012), a higher number of leaves in expansion and a smaller number of senescent leaves (PAIVA et al., 2012), resulting in higher nutrient levels (SANTOS et al., 2006). Thus, if this same response pattern can be obtained in pastures submitted to deferment, changing the population age profile via strategic nitrogen fertilisation can potentially increase leaf and total accumulation of forage. 
Depending on the application strategy, nitrogen fertilisation may have different effects on the dynamics of the renewal of the tiller population in deferred pastures. The distribution of fertiliser during the period of higher pasture growth, prior to deferment, can lead to high rates of tiller appearance and mortality (CAMINHA et al., 2010), maintaining a more youthful profile of the tiller population at the beginning of the deferral period. On the other hand, nitrogen application only at the beginning of the deferment period would only be effective in increasing the renewal of tillers during deferment if the growth factors an ensure physiological independence and/or the adequate development of the root system, which is essential to the survival of young tillers (ONG, 1978) that may have been produced during the deferment period.

Although the importance of strategic nitrogen fertilisation is widely recognised, its effects on the tissue flow of individual tillers, the age profile of the tiller population and tillering, main mechanisms driven by nitrogen availability (PAIVA et al., 2011; SANTOS; FONSECA, 2016), have been poorly investigated.
Based on the above, the objective of this work was to evaluate the effects of the nitrogen fertiliser application strategy on the morphogenic characteristics and the number of young, mature and old tillers in two phases, initial and final deferment period, of Marandu grass.

\section{Materials and Methods}

The experiment was carried out between January and June 2014 at the Capim-Branco Experimental Farm, Federal University of Uberlândia, in Uberlândia, MG, Brazil (1853'19 "S, 48²0'57" W; $863 \mathrm{~m}$ above sea level). In this tropical highelevation climate (ALVARES et al., 2013), the dry and rainy seasons are well-defined, with an annual average temperature and precipitation of $22.3^{\circ} \mathrm{C}$ and $1,584 \mathrm{~mm}$, respectively. During the experimental period, climatic data were obtained at a meteorological station located $200 \mathrm{~m}$ away from the experimental site (Figure 1A). Mean temperature and total rainfall data were used to calculate the monthly soil water balance (THORNTHWAITE; MATHER, 1955), considering a soil water storage capacity of $60 \mathrm{~mm}$ (Figure 1B).

Figure 1. Monthly rainfall and average minimum, mean and maximum air temperatures (A); and monthly soil water balance (B) on the experimental site from January to June 2014.
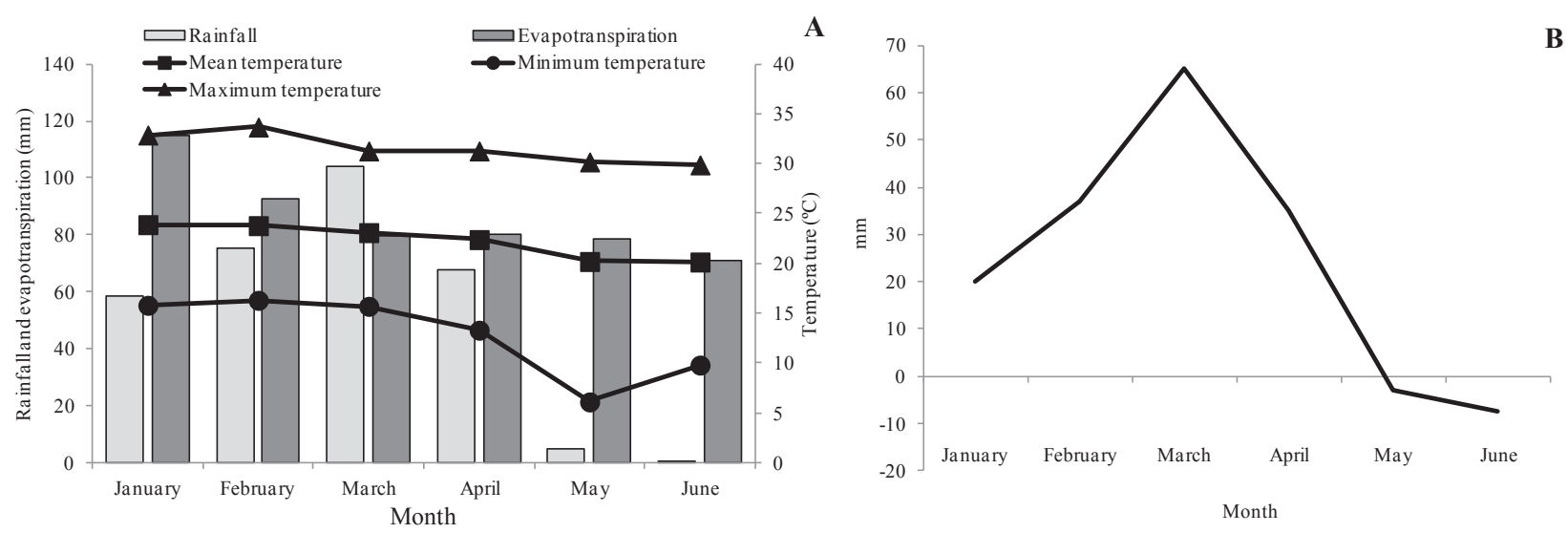

The studied forage species was Brachiaria brizantha syn. Urochloa brizantha Stapf. cv. Marandu (Marandu grass), established in 2000 and with no evidence of degradation. The chemical characteristics of the soil in the 0 to $20-\mathrm{cm}$ layer were as follows: $\mathrm{pH}$ in $\mathrm{H}_{2} \mathrm{O}: 5.5$; $\mathrm{P}: 1.3 \mathrm{mg} \mathrm{dm}^{-3}$ 
(Mehlich-1); K: $75 \mathrm{mg} \mathrm{dm}^{-3} ; \mathrm{Ca}^{2+}: 1,7 \mathrm{cmol}_{\mathrm{c}} \mathrm{dm}^{-}$ 3; $\mathrm{Mg}^{2+}: 1,1 \mathrm{cmol}_{\mathrm{c}} \mathrm{dm}^{-3} ; \mathrm{Al}^{3+}: 0,0 \mathrm{cmol}_{\mathrm{c}} \mathrm{dm}^{-3}(\mathrm{KCl}$ $1 \mathrm{~mol} \mathrm{~L}^{-1}$ ) and P-rem: $11.7 \mathrm{mg} \mathrm{dm}^{-3}$. Based on the results, liming was not performed. Maintenance fertilisation was carried out on January 10, 2014, by applying the equivalent of $50 \mathrm{~kg} \mathrm{ha}^{-1}$ of $\mathrm{K}_{2} \mathrm{O}$ and $\mathrm{P}_{2} \mathrm{O}_{5}$, using potassium chloride and simple superphosphate, respectively.

The experimental area was divided into eight $9-\mathrm{m}^{2}$ plots. In each plot, the canopy was maintained at a height of $30 \mathrm{~cm}$ from October 2013 to March 2014, according to the recommendations of Silva et al. (2013) for grazing management in continuous stocking. For this, weekly cuts were performed, and the excess forage was removed from the experimental units.

The following two nitrogen fertilisation strategies were evaluated: low-dose fertilisation using $50 \mathrm{~kg} \mathrm{ha}^{-1}$ of nitrogen $(\mathrm{N})$, applied at the beginning of the deferment period on 03/07/2014, and high-dose fertilisation using $200 \mathrm{~kg} \mathrm{ha}^{-1}$ of $\mathrm{N}$, divided into three applications: $80 \mathrm{~kg} \mathrm{ha}^{-1}$ (applied on $01 / 10 / 2014$ ), $70 \mathrm{~kg} \mathrm{ha}^{-1}$ (applied on $02 / 17 / 2014$ ) and $50 \mathrm{~kg}$ ha-1 (applied on 03/06/2014). The nitrogen source was urea, and fertilisation took place in the late afternoon.

In all plots, the age of the tillers that composed the population was monitored from October 2013. For this purpose, two areas representative of the conditions of the plot were selected at the time of the first marking and delimited by PVC pipe of $30 \mathrm{~cm}$ in diameter. At the first marking, all tillers within the sampling area were marked with plastic wires of a specific colour. New tillers were marked at intervals of 30 days, using differently coloured wires to identify each generation. At the beginning of the deferral period, in March 2014, all tillers were identified, and counted and partitioned onto different age groups: young tillers (less than 2 months old), mature tillers (2 to 4 months old) and old tillers (more than 4 months old), according to a previous study (PAIVA et al., 2015). This approach enabled us to determine the population density of tillers of each age group; the results were expressed in tiller $\mathrm{m}^{-2}$.

In each plot, four tillers were selected from each age group, and their morphogenic characteristics were monitored during the deferral period, which was 90 days (03/07/2014 to 06/06/2014). Leaf blade and stem length (stem + pseudostem) were measured weekly, using a ruler graduated in centimetres. The length of the expanded leaves was measured from the tip of the leaf to its ligule. In the case of expanding leaves, the same procedure was adopted; however, the last expanded leaf ligule was considered as the measurement reference. For leaves in senescence, the length corresponded to the distance between its ligule and the point where the senescence process progressed (green portion of the leaf blade). Stem size corresponded to the distance from the soil surface to the ligule of the youngest fully expanded leaf. Based on this information, we calculated the following parameters:

Leaf appearance rate (leaf tiller day ${ }^{-1}$ ): number of leaves appeared per tiller divided by the number of days of the evaluation period;

Leaf elongation rate $\left(\mathrm{cm}\right.$ tiller day $\left.^{-1}\right)$ : sum of positive length variations of leaf blades per tiller divided by the number of days of the evaluation period;

Stem elongation rate $\left(\mathrm{cm}\right.$ tiller day $\left.^{-1}\right)$ : sum of positive length variations of stems per tiller divided by the number of days of the evaluation period;

Leaf live duration (LLD): estimated by the equation LLD $\left(\right.$ days leaf $\left.{ }^{-1}\right)=$ number of live leaves (NLL) $\mathrm{x}$ philocrone (LEMAIRE; CHAPMAN, 1996), where NLL corresponds to the average number of fully expanded leaves per tiller, including leaves with less than $50 \%$ of senescent leaf length, and philocrone, corresponding to the inverse of the lead appearance rate;

Leaf senescence rate $\left(\mathrm{cm}\right.$ tiller day $\left.^{-1}\right)$ : sum of negative length variations of leaf blades per tiller divided by the number of days of the evaluation 
period.

The main treatments (nitrogen fertilisation strategies) were distributed in a completely randomised design in a sub-subdivided plot scheme with four replications $\left(9-\mathrm{m}^{2}\right.$ plots). The nitrogen fertilisation strategies corresponded to the different plots the age categories of tillers to the subplots and the periods of deferral to the sub-sub-plot. The data were checked for prerogatives to perform analysis of variance. As the LLD and the stem elongation rate did not meet the assumptions of the analysis of variance, they were analysed in a non-parametric statistical test. All analyses were performed at the significance level of up to $5 \%$ of probability for type I error, and once significant effects were detected, the means were compared by the $t$ test.

\section{Results and Discussion}

Tiller population density was influenced by the interactions between tiller age $\mathrm{x}$ deferment phase $(\mathrm{P}$ $=0.0008)$ and tiller age $\mathrm{x}$ fertilisation strategy $(\mathrm{P}=$ 0.0034). In the initial phase of the deferment period, the population densities of young and old tillers were similar, while lower values were recorded for mature tillers (Figure 2A).
Deferral period had a greater influence on the number of young tillers, with a reduction of $22 \%$ from the beginning to the end of this period. The tillers of this age group, at the beginning of the deferment period, corresponded to the generations that appeared between January and February, a season of intense population renewal (SBRISSIA et al., 2010). In this sense, the agronomic and management strategies adopted in these months of the year have a significant impact on the percentage of young tillers at the time of deferral. Nitrogen fertilisation is able to stimulate increases in tillering rates at this time of year (MORAIS et al., 2006; CAMINHA et al., 2010), contributing to the higher population density of young tillers in the early phase of the deferral period (Figure 2B). Deferment is a management strategy that facilitates a high competition for light between the tillers, so that the scarce quantity and the low quality of light that arrives at the base of the canopy during the deferment period decreases the appearance of new individuals from buds and the mortality of some young and smaller tillers (ONG, 1978). Thus, the age profile of the tiller population in the canopy changed during the deferment period (Figures 2A and 3), independently of the nitrogen fertilisation strategy adopted.

Figure 2. Number of young, mature and old tillers of Marandu palisade grass fertilized with low (50 kg ha-1) or high (200 $\mathrm{kg} \mathrm{ha}^{-1}$ ) nitrogen dose (A) and at the beginning and at the end of the deferment period (B).
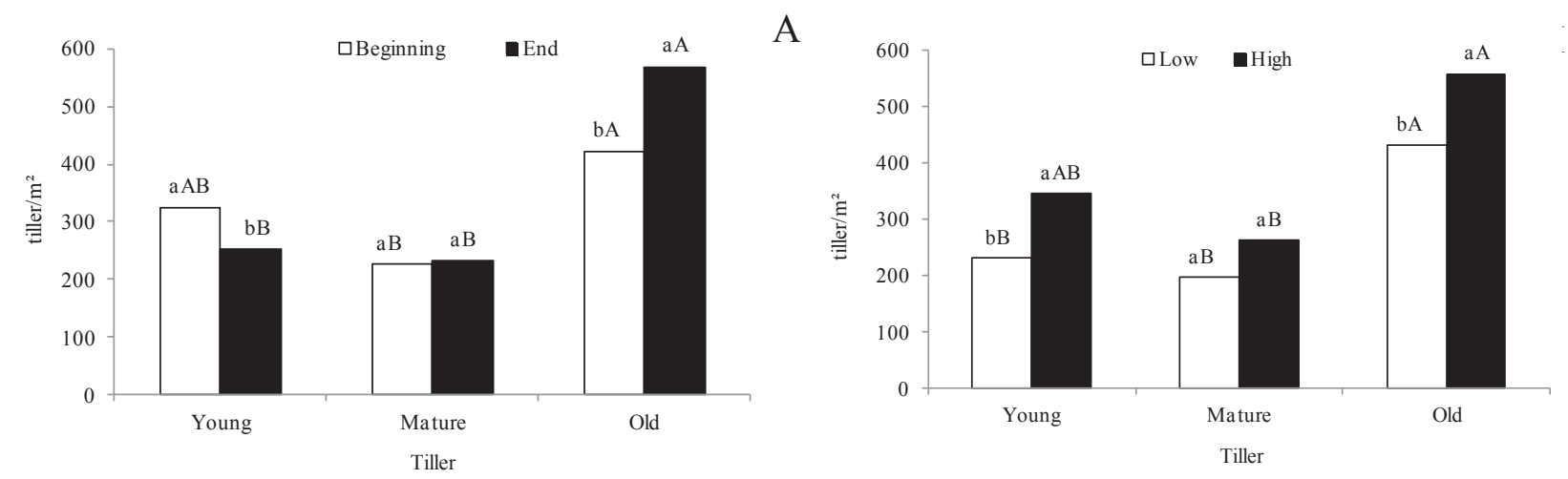

A: Lowercase letters compare the deferment periods within each tiller age and uppercase letters compare the tiller ages within each deferment period by the $t$ test $(\mathrm{P}<0.05)$.

$\mathrm{B}$ : Lowercase letters compare the nitrogen doses within each tiller age and uppercase letters compare the tiller ages within each nitrogen dose by the $\mathrm{t}$ test $(\mathrm{P}<0.05)$. 
Between the initial and final phases of the deferment period, the population density of old tillers increased by approximately $35 \%$, while no significant variations were observed in the population density of mature tillers. The prevalence of a population of plants composed of older individuals during the winter compared to the other age groups has also been reported by Paiva et al. (2011) in Marandu grass managed under continuous stocking and submitted to nitrogen fertilisation. According these authors, the restricted availability of growth factors induces the plant community to adjust their patterns of tillering dynamics, triggering conservation strategies. These strategies are characterised by the maintenance of low tillering rates, associated to the increase in the survival rates of the individuals that compose the population (CAMINHA et al., 2010). Changes in the flow of individual tiller foliar tissues, such as decreases in leaf appearance and elongation rates, as well as the maintenance of longer leaves, are also part of the set of conservation strategies (SANTOS et al., 2011, 2013).

Figure 3. Number of young, mature and old tillers during the deferment period of the Marandu palisade grass canopy fertilized with high (A, $\left.200 \mathrm{~kg} \mathrm{ha}^{-1}\right)$ or low (B, $\left.50 \mathrm{~kg} \mathrm{ha}^{-1}\right)$ nitrogen dose.

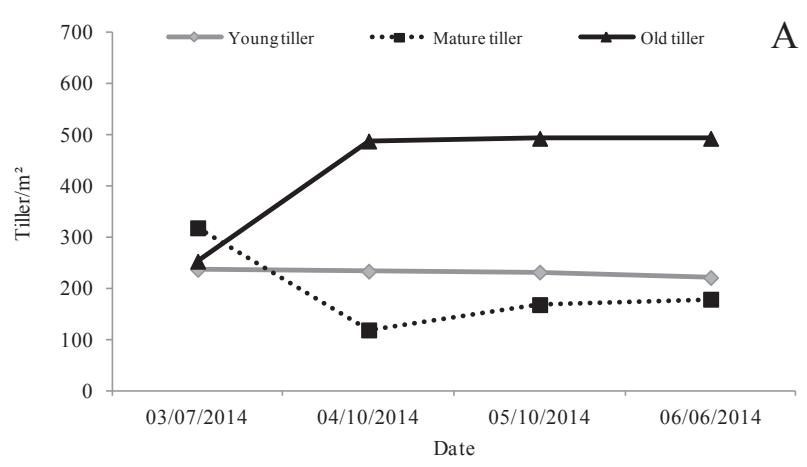

The old tillers present in the final phase of the deferment period corresponded to the same generations produced in January and February, which highlights the importance of nitrogen fertilisation in the months prior to deferment, the season of higher canopy growth, and not only for the start of the deferral period. This response pattern was confirmed, considering that the fertilisation strategy greatly affected the total population density and the composition of the tiller population (Figures 2B and 3 ). The forage canopy that received the highest dose of $\mathrm{N}$, which was distributed throughout the growing season, maintained, on average, 1,167 tillers $\mathrm{m}^{-2}$, while the canopy fertilised with only $50 \mathrm{~kg}$ of $\mathrm{N} \mathrm{ha}^{-1}$ at the beginning of the deferment period contained $859 \mathrm{~m}^{-2}$ tillers. Additionally, considering the mean values between the two phases of the deferment period, the canopy that received the highest $\mathrm{N}$ dose maintained higher population densities of young

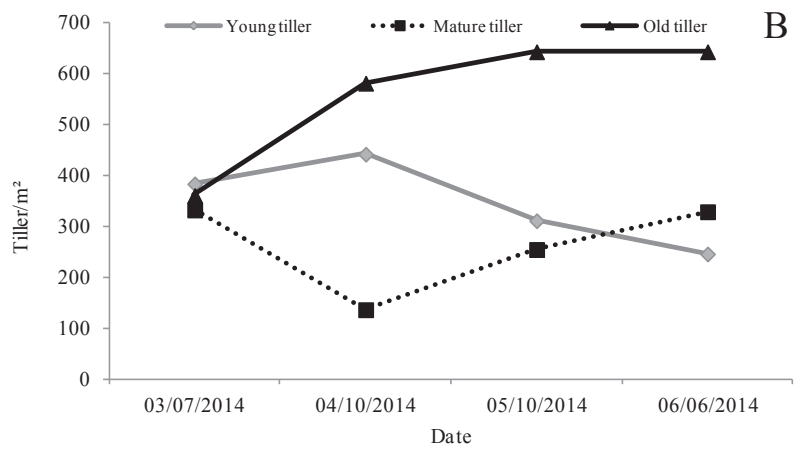

and old tillers compared to that managed with a lower nitrogen dose (Figures 2B and 3).

The characteristics that express the flow of foliar tissues in the individual tillers are represented by the rates of appearance (LAR), elongation (LER) and leaf senescence (LSR) and were influenced by the age group, particularly in the initial phase of the deferment period. The marked phase effect of deferral on the morphogenic characteristics of the plants ratifies the change in the growth strategy, prevailing to the conservation of resources, with the advancement of the deferment period.

There was an effect of tiller age $(\mathrm{P}=0.0804)$ on LAR. Young and mature shoots had higher mean values of LAR $(0.040 \pm 0.0054$ and $0.041 \pm 0.0051$ leaves tiller ${ }^{-1}$ day $^{-1}$, respectively) and similar ones, while old tillers maintained a lower leaf appearance rate $\left(0.028 \pm 0.0053\right.$ leaves tiller ${ }^{-1}$ day $\left.^{-1}\right)$. Variations in 
LAR were also observed according to the interaction between fertilisation strategy and deferral phase ( $P$ $=0.0177)$. In both fertilisation strategies, the highest LAR occurred in the initial deferment phase (Figure 4). However, the fertilisation strategy characterised by the higher $\mathrm{N}$ dose resulted in higher LAR values at the beginning of the deferment period, while canopy tillers receiving lower $\mathrm{N}$ doses were able to maintain higher LAR values in the final phase of the deferment period (Figure 4).

Figure 4. Leaf appearance rate of Marandu palisade grass fertilized with high $\left(200 \mathrm{~kg} \mathrm{ha}^{-1}\right)$ or low $\left(50 \mathrm{~kg} \mathrm{ha}^{-1}\right)$ nitrogen dose at the beginning and end of the deferment period.

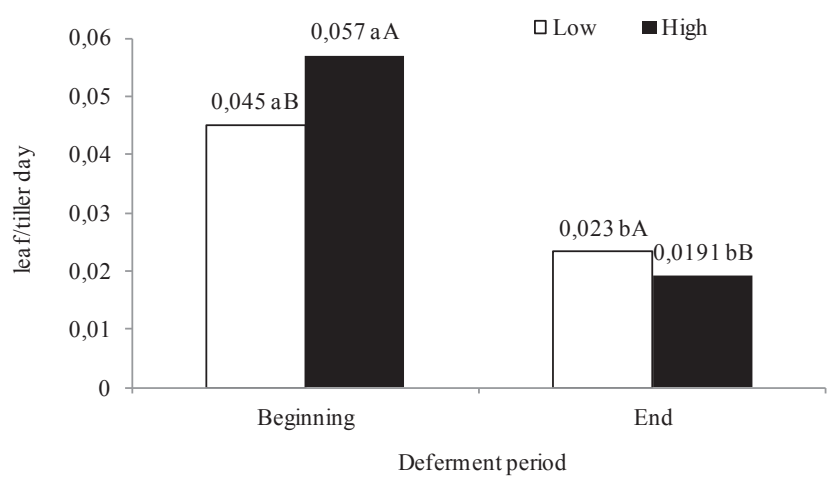

Upper case letters compare the nitrogen doses within the deferment periods, and lower case letters compare the deferment periods within the nitrogen doses by the t test $(\mathrm{P}<0.05)$.

The leaf elongation rate (LER) varied with the interaction effects of fertilisation $\mathrm{x}$ phase of deferment $(\mathrm{P}<0.001)$ and the age group effect of the tiller $\mathrm{x}$ phase of the deferment period $(\mathrm{P}<$ $0.001)$. Fertilisation with a higher $\mathrm{N}$ dose resulted in higher LER values in the initial phase of deferment (Figure 5A). However, this effect disappeared in the final deferral phase. Nitrogen is an important plant nutrient and required in several physiological processes that determine the flow of foliar tissues (GASTAL; NELSON, 1994), thus having marked effects on LER in several tropical forage grasses (MARTUSCELLO et al., 2005; FAGUNDES et al., 2006; PACIULLO et al., 2011). Paiva et al. (2011) have demonstrated that leaf tissue flow increases with nitrogen fertilisation, and this effect was more marked in young tillers, since the authors observed no increases in LER with increasing $\mathrm{N}$ doses in old tillers. The same response pattern was recorded in the present experiment, with the young tillers expressing greater leaf elongation in the initial phase of the deferment period. At the end of this period, young and mature tillers maintained higher LER values compared to old tillers (Figure 5B).

The differences in the growth potential according to the age group of the individuals may be related to the anatomical and physiological changes in the stage of maturity, such as increases in the percentages of conducting and supporting tissues (PINTO et al., 1994), which greatly influence the photosynthetic potential of leaves and tillers. In this sense, Yasuoka et al. (2017) have demonstrated that the fully expanded or younger fully expanded leaf blades of Mulato II Brachiaria grass [B. brizantha $\mathrm{x}$ $B$. decumbens $\mathrm{x}$ B. ruziziensis (syn. U. brizantha $\mathrm{x}$ $U$. decumbens $\mathrm{x} U$. ruziziensis) ] are able to maintain a photosynthetic potential about $52 \%$ higher than that registered in mature leaf blades. Additionally, with an increase in nitrogen fertilisation from 50 to $250 \mathrm{~kg} \mathrm{ha}^{-1}$ of $\mathrm{N}$, the photosynthetic rates increased by $24.6,31.0$ and $25.0 \%$ in growing leaf blades, younger completely expanded blades and mature blades, respectively. 
Figure 5. Leaf elongation rate of the Marandu palisade grass fertilized with high (200 kg ha-1) or low (50 $\left.\mathrm{kg} \mathrm{ha}^{-1}\right)$ nitrogen dose (A) and in age groups of tillers at the beginning and end of the deferment period (B).
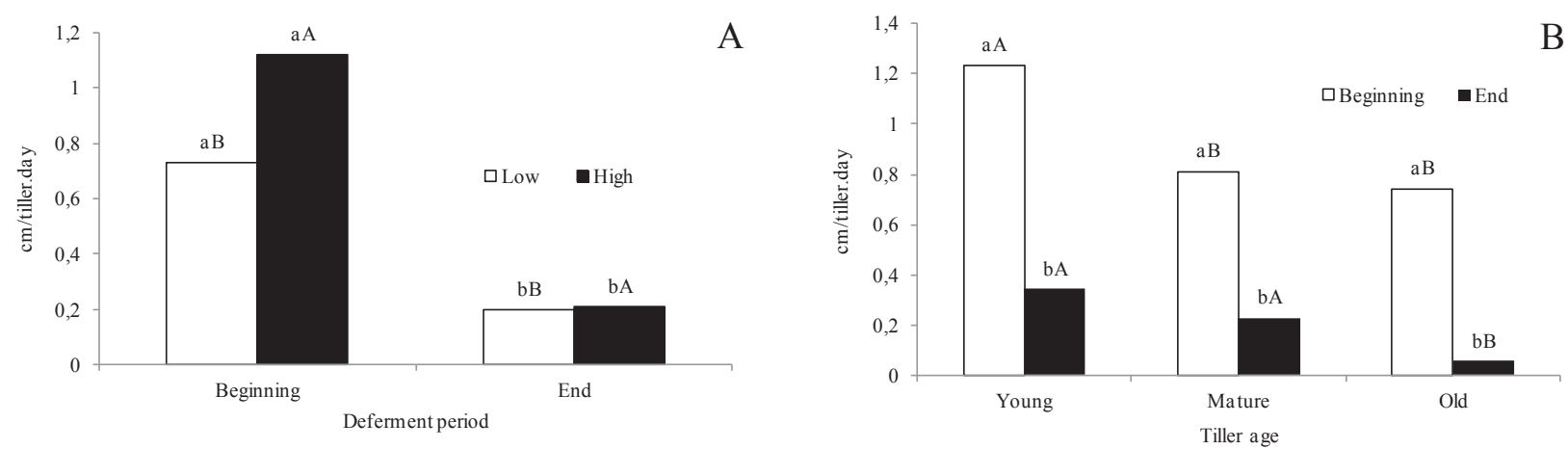

A: Upper case letters compare the nitrogen doses within the deferment period and lower case letters compare the deferment periods within the nitrogen dose by the $\mathrm{t}$ test $(\mathrm{P}<0.05)$.

$\mathrm{B}$ : Capital letters compare the tiller ages within each deferment period and lowercase letters compare the deferment periods within each tiller age by the $\mathrm{t}$ test $(\mathrm{P}<0.05)$.

The leaf senescence rate (LSR) was significantly influenced by the $\mathrm{N}$ dose $(\mathrm{P}=0.0024)$ and by the deferment period $(\mathrm{P}=0.0001)$. The levels were higher in Marandu grass fertilised with high $\mathrm{N}$ dose $\left(1.0 \pm 0.10 \mathrm{~cm}\right.$ tiller ${ }^{-1}$ day $\left.^{-1}\right)$ when compared to low-dose fertilisation $\left(0.7 \pm 0.07 \mathrm{~cm}_{\text {tiller }}{ }^{-1}\right.$ day $\left.^{-1}\right)$. Nitrogen increases the flow of tissues in the plant, so that, concurrently with the higher generation and growth of foliar tissue, the senescence of the plant accelerates (MARTUSCELLO et al., 2005; FAGUNDES et al., 2006). In addition, the restrictive climatic conditions at the end of the deferment period (Figure 1) resulted in higher LSR values $\left(1.1 \pm 0.09 \mathrm{~cm}\right.$ tiller $\left.{ }^{-1} \mathrm{day}^{-1}\right)$ when compared to the initial deferment phase $\left(0.6 \pm 0.06 \mathrm{~cm}^{\text {tiller }}{ }^{-1}\right.$ day $\left.^{-1}\right)$. Nevertheless, a longer lifespan of leaves was recorded at the end of the deferral period (120 \pm 18.0 days leaf $^{-1}$ ) compared to the beginning (69 \pm 2.3 days leaf $\left.{ }^{-1}\right)$ of deferment $(\mathrm{P}=0.0150$ for the deferment phase). The lower leaf lifespan (LLD) in the initial phase of the deferment period can be associated with the greater renewal of Marandu grass tissues (high LAR and LER). On the other hand, the higher LLD at the end of deferment may represent a strategy for maintaining the photosynthetic surface at a time when tissue turnover is slow.
The stem elongation rate (SER) was influenced only by the deferment phase, being higher at the beginning $\left(0.17 \pm 0.04 \mathrm{~cm}_{\text {tiller }}^{-1}\right.$ day $\left.^{-1}\right)$ than at the end $\left(0.01 \pm 0.01 \mathrm{~cm} \mathrm{tiller}^{-1} \mathrm{day}^{-1}\right)$ of the deferment period. The higher plant growth rate in the initial period, favoured by more suitable environmental conditions (Figure 1), promoted higher LAR and LER values. Therefore, to sustain these leaves and to allocate them in the upper part of the canopy, support structures are necessary. For this reason, the highest SER values occurred concomitantly with the highest LAR and LER values.

Our results lead us to infer that age is a determining factor of the morphogenic characteristics of the Marandu grass tillers submitted to deferment. This strong effect of ontogeny on tiller growth indicates an additional level of complexity in the study of morphogenesis of tropical forage grasses as compared to temperate grasses (PAIVA et al., 2011). In terms of practical limitations, there is evidence that the agronomic and management strategies of pasture deferment could be further optimised to alter the age profile of the population, with the aim to reduce the average tiller age in the pasture. This could contribute to increased leaf tissue production in the pasture. As shown in the present work, among 
the agronomic tools capable of increasing the relative participation of young tillers in the deferred canopy, nitrogen fertilisation with higher $\mathrm{N}$ doses, with applications parcelled out during the season of greatest growth prior to deferment, corresponded to the study region for the months of January, February and early March.

\section{Conclusions}

In Brachiaria brizantha cv. Marandu canopies, the highest dose of nitrogen fertiliser, parcelled out before deferment, results in an increased number of young tillers in the initial deferment phase. Young tillers have a higher growth potential than old ones, although old tillers are more prevalent in the canopy as the deferment period is prolonged.

\section{Acknowledgements}

The authors would like to thank the Fundação de Amparo à Pesquisa do Estado de Minas Gerais, the Conselho Nacional de Desenvolvimento Científico e Tecnológico (CNPq) and the Fundação de Apoio Universitário for funding. Thanks are also due to graduates of the Study and Research Group in Forage Culture of the Federal University of Uberlândia for their contribution to this project.

\section{References}

ALVARES, C. A.; STAPE, J. L.; SENTELHAS, P. C.; GONÇALVES, J. L. M.; SPAROVEK, G. Köppen's climate classification map for Brazil. Meteorologische Zeitschrift, Stuttgart, v. 22, n. 6, p. 711-728, 2013. DOI: 10.1127/0941-2948/2013/0507

BARBOSA, R. A.; NASCIMENTO JUNIOR, D.; VILELA, H. H.; SOUSA, B. M. L.; SILVA, S. C.; EUCLIDES, V. P. B.; SILVEIRA, M. C. T. Morphogenetic and structural characteristics of guinea grass tillers at different ages under intermittent stocking. Revista Brasileira de Zootecnia, Viçosa, MG, v. 41, n. 7, p. 15831588, 2012. DOI: $10.1590 / \mathrm{S} 1516-35982012000700005$

CAMINHA, F. O.; SILVA, S. C. da; PAIVA, A. J.; PEREIRA, L. E. T.; MESQUITA, P.; GUARDA, V. D.
Estabilidade da população de perfilhos de capim-marandu sob lotação contínua e adubação nitrogenada. Pesquisa Agropecuária Brasileira, Brasília, v. 45, n. 2, p. 213-220, 2010. DOI: 10.1590/S0100-204X2010000200013

FAGUNDES, J. L.; FONSECA, D. M.; MISTURA, C.; MORAIS, R. V.; VITOR, C. M. T.; GOMIDE, J. A.; NASCIMENTO JUNIOR, D.; CASAGRANDE, D. R.; COSTA, L. T. Características morfogênicas e estruturais do capim-braquiária em pastagem adubada com nitrogênio avaliadas nas quatro estações do ano. Revista Brasileira de Zootecnia, Viçosa, MG, v. 35, n. 1, p. 2129, 2006. DOI: 10.1590/S1516-35982006000100003

GASTAL, F.; NELSON, C. J. Nitrogen use whitin the growing leaf blade of tall fescue. Plant Physiology, Illinois, v. 105, n. 1, p. 191-197, 1994. DOI: 10.1104/ pp.105.1.191

LEMAIRE, G.; CHAPMAN, D. Tissue flows in grazed plant communities. In: HODGSON, J.; ILLIUS, A. W. (Ed.). The ecology and management of grazing systems. Wallingford: CAB international, 1996. p. 3-36.

MARTUSCELLO, J. A.; FONSECA, D. M.; NASCIMENTO JUNIOR, D.; SANTOS, P. M.; RIBEIRO JUNIOR, J. I.; CUNHA, D. N. F. V.; MOREIRA, L. M. Características morfogênicas e estruturais do capimxaraés submetido à adubação nitrogenada e desfolhação. Revista Brasileira de Zootecnia, Viçosa, MG, v. 34 , n. 5 , p. $1475-1482$, 2005. DOI: $10.1590 / \mathrm{S} 1516-$ 35982005000500007

MORAIS, R. V.; FONSECA, D. M.; NASCIMENTO JUNIOR, D.; RIBEIRO JUNIOR, J. I.; FAGUNDES, J. L.; MOREIRA, L. M.; MISTURA, C.; MARTUSCELLO, J. A. Demografia de perfilhos basilares em pastagens de Brachiaria decumbens adubada com nitrogênio. Revista Brasileira de Zootecnia, Viçosa, MG, v. 35, n. 2, p. 380388, 2006. DOI: 10.1590/S1516-35982006000200007

ONG, C. K. The physiology of tiller death in grasses. 1. The influence of tiller age, size and position. Journal of the British Grassland Society, Aberystwyth, v. 33, n. 3, p. 197-203, 1978. DOI: 10.1111/j.1365-2494.1978. tb00820.x

PACIULLO, D. S. C.; FERNANDES, P. B.; GOMIDE, C. A. M.; CASTRO, C. R. T.; SOBRINHO, F. S.; CARVALHO, C. A. B. The growth dynamics in Brachiaria species according to nitrogen dose and shade. Revista Brasileira de Zootecnia, Viçosa, MG, v. 40, n. 2, p. 270276, 2011. DOI: 10.1590/S1516-35982011000200006

PAIVA, A. J.; PEREIRA, L. E. T.; SILVA, S. C.; DIAS, R. A. P. Identification of tiller age categories based on morphogenetic responses of continuously stocked marandu palisade grass fertilized with nitrogen. Ciência 
Rural, Santa Maria, v. 45 , n. 5, p. $867-870,2015$. DOI: 10.1590/0103-8478cr20120738

PAIVA, A. J.; SILVA, S. C.; PEREIRA, L. E. T.; CAMINHA, F. O.; PEREIRA, M. P.; GUARDA, V. D. Morphogenesis on age categories of tillers in marandu palisadegrass. Scientia Agricola, Piracicaba, v. 68 , n. 6 , p. $626-631,2011$. DOI: $10.1590 / \mathrm{S} 0103-$ 90162011000600003

PAIVA, A. J.; SILVA, S. C.; PEREIRA, L. E. T.; GUARDA, V. D.; PEREIRA, M. P.; CAMINHA, F. O.; Structural characteristics of tiller age categories of continuously stocked marandu palisade grass swards fertilized with nitrogen. Revista Brasileira de Zootecnia, Viçosa, MG, v. 41, n. 1, p. 24-29, 2012. DOI: 10.1590/ S1516-35982012000100004

PINTO, J. C.; GOMIDE, J. A.; MAESTRI, M. Produção de matéria seca e relação folha/caule de gramíneas forrageiras tropicais, cultivadas em vaso, com duas doses de nitrogênio. Revista Brasileira Zootecnia, Viçosa, v. 23, n. 3, p. 313-326, 1994.

SANTOS, M. E. R.; FONSECA, D. M. Adubação de pastagens em sistemas de produção animal. Viçosa, MG: Editora UFV, 2016. 311 p.

SANTOS, M. E. R.; FONSECA, D. M.; GOMES, V. M. Relações entre morfogênese e dinâmica do perfilhamento em pastos de capim-braquiária. Bioscience Journal, Uberlândia, v. 30, n. 1, p. 201-209, 2013.

SANTOS, M. E. R.; FONSECA, D. M.; EUCLIDES, V. P. B.; RIBEIRO JUNIOR, J. I. R.; NASCIMENTO JUNIOR, D.; MOREIRA, L. M. Produção de bovinos em pastagem de capim-braquiária diferido. Revista Brasileira de Zootecnia, Viçosa, MG, v. 38, n. 4, p. 635642, 2009. DOI: 10.1590/S1516-35982009000400007

SANTOS, M. E. R.; FONSECA, D. M.; GOMES, V. M.; GOMIDE, C. A. M.; NASCIMENTO JUNIOR, D.; QUEIROZ, D. S. Capim-braquiária sob lotação contínua e com altura única ou variável durante as estações do ano: morfogênese e dinâmica de tecidos. Revista Brasileira de Zootecnia, Viçosa, MG, v. 40, n. 11, p. 2323-2331, 2011. DOI: $10.1590 / \mathrm{S} 1516-35982011001100007$

SANTOS, P. M.; CORSI, M.; PEDREIRA, C. G. S. Tiller cohort development and digestibilidade in Tanzania guinea grass (Panicum maximum cv Tanzania) under three levels of grazing intensity. Tropical Grasslands, Brisbane, v. 40, n. 2, p. 84-93, 2006.

SBRISSIA, A. F.; SILVA, S. C. da; SARMENTO, D. O. L.; MOLAN, L. K.; ANDRADE, F. M. E.; GONÇALVES, A. C.; LUPINACCI, A. V. Tillering dynamics in palisadegrass swards continuously stocked by cattle. Plant Ecology, Switzerland, v. 206, n. 2, p. 349359, 2010. DOI: 10.1007/s11258-009-9647-7

SILVA, C. S.; MONTAGNER, D. B.; EUCLIDES, V. P. B.; QUEIROZ, C. A.; ANDRADE, R. A. S. Steer performance on deferred pastures of Brachiaria brizantha and Brachiaria decumbens. Ciência Rural, Santa Maria, v. 46 , n. 11 , p. $1998-2004$, 2016. DOI: $10.1590 / 0103-$ $8478 \mathrm{cr} 20151525$

SILVA, S. C. da; GIMENES, F. M. A.; SARMENTO, D. O. L.; SBRISSIA, A. F.; OLIVEIRA, D. E.; HERNADEZ-GARAY, A.; PIRES, A. V. Grazing behaviour, herbage intake and animal performance of beef cattle heifers on marandu palisade grass subjected to intensities of continuous stocking management. Journal of Agricultural Science, Cambridge, v. 151, n. 5, p. 727739, 2013. DOI: $10.1017 / \mathrm{S} 0021859612000858$

SOUSA, B. M. L.; SANTOS, M. E. R.; VILELA, H. H.; SILVEIRA, M. C. T.; ROCHA, G. O.; FREITAS, C. A. S.; SILVA, N. A. M.; NASCIMENTO JUNIOR, D. Piata palisade grass deferred with two distinct initial heights: luminous environment and tillering dynamics. Revista Brasileira de Zootecnia, Viçosa, MG, v. 42, n. 1, p. 3643, 2013. DOI: 10.1590/S1516-35982013000100006

SOUSA, B. M. L.; VILELA, H. H.; SANTOS, A. L.; SANTOS, M. E. R.; NASCIMENTO JÚNIOR, D.; ASSIS, C. Z.; FARIA, B. D.; ROCHA, G. O. Piata palisadegrass deferred in the fall: effects of initial height and nitrogen in the sward structure. Revista Brasileira de Zootecnia, Viçosa, MG, v. 41, n. 5, p. 1134-1139, 2012. DOI: $10.1590 / \mathrm{S} 1516-35982012000500008$

TEIXEIRA, F. A.; PIRES, A. J. V.; SILVA, F. F.; FRIES, D. D.; REZENDE, C. P.; COSTA, A. C. P. R.; SANTOS, T. C.; NASCIMENTO, P. V. N. Estratégias de adubação nitrogenada, características morfogênicas e estruturais em pastos de Brachiaria decumbens diferidos por 95 dias. Semina: Ciências Agrárias, Londrina, v. 35, n. 2, p. $987-$ 998, 2014. DOI: 10.5433/1679-0359.2014v35n2p987

THORNTHWAITE, C. W.; MATHER, J. R. The water balance. Publications in climatology. New Jersey: Drexel Institute of Technology, 1955. $104 \mathrm{p}$.

YASUOKA, J. I.; PEDREIRA, C. G. S.; SILVA, V. J. da; ALONSO, M. P.; SILVA, L. S. da; GOMES, F. J. Canopy height and $\mathrm{N}$ affect herbage accumulation and the relative contribution of leaf categories to photosynthesis of grazed brachiariagrass pastures. Grass and Forage Science, Cheshire, v. 73, n. 1, p. 183-192, 2017. DOI: $10.1111 /$ gfs. 12302 